\title{
Flow Patterns in an Air Conditioned Playground Zone of Football Stadium
}

\author{
Khalil EE*, El-Bialy EM, Abdel-Maksoud W and Ashmawy ME \\ Faculty of Engineering, Department of Mechanical Power Engineering, Cairo University, Giza, Egypt
}

\begin{abstract}
In this paper, research on developing air conditioning systems in playground zone of stadium by employing several kinds of technologies to cool the outdoor spaces. The most serious challenge of air conditioning in playground zone in stadium is difficult to control the temperature and humidity in the outdoor area and also the enormous energy needed by the cooling system to maintain thermal comfort conditions within the football playground area. The main task for the analyzed model was to ensure the better method to distribute air to achieve the human comfortable for players and reduce the cooling capacity of playground zone by covering this zone using a large sunshade to reduce the sun's rays and maintain the stadium's temperature. The technical aspect was addressed by developing an empirical mathematical model for the performance of stadium model. The result of the study concludes that the system designed in Qatar stadium for conditioning and distribution air and evaluates results by using Computational Fluid Dynamics CFD code to determine the best way to distribute the air inlets and simulating the flows in air to overcome the high temperature and humidity to reach the human comfortable for players.
\end{abstract}

\section{Keywords: Football; Air; Flow}

Nomenclature: CFD: Computational Fluid Dynamics; t: Time (s); T: Dry bulb temperature of gas mixture $\left({ }^{\circ} \mathrm{C}\right)$; T": Temperature fluctuation $\left({ }^{\circ} \mathrm{C}\right)$; u: Instantaneous velocity component in $\mathrm{x}$ direction $(\mathrm{m} / \mathrm{s})$; v: Instantaneous velocity component in y direction $(\mathrm{m} / \mathrm{s})$; w: Instantaneous velocity component in $\mathrm{z}$ direction $(\mathrm{m} / \mathrm{s})$; $\mathrm{U}$ : Axial velocity; V: Computational cell volume $\left(\mathrm{m}^{3}\right) ; \mathrm{Y}$ : Mass fraction of species (j); $x, y, z$ : Cardinal coordinate components.

\section{Introduction}

In Qatar, the hot outdoor climate induces a need for cooling to reach the human comfortable. Outdoor air conditioning is rather complicated and its complexity is increasing with the advancement of technology. Nowadays, the Qatar 2022 World Cup organizing committee suggests the solution of this problem to move the tournament to the winter, when temperatures will be cooler.

It's going to be an enormous engineering challenge to conditioning the outdoor areas, because as global temperatures increase over the next century and then there is going to be greater demand for sustainable air conditioning, not just in football stadium but for the growing number of people who will find themselves living in hot and humid parts of the world. This is the essence of the problem in Qatar with the football stadiums, where it shall be needed to install huge air conditioning systems and shut the roof to make them effective and energy efficient and that in turn has several consequences. A better approach is to develop new ways of air-conditioning large stadiums using new mechanisms such as evaporative cooling, solar energy and computercontrolled shades that track the sun. In addition using CFD Program to determine the best way to conditioning playground area for players to create a temperate environment inside the Qatar stadiums and achieve the human comfortable, so It was the work of a simplified simulation model for analyzing the results of Qatar stadium by CFD Software and distribute the air inlets to achieve the best distribution of air and specify the influence of air on players and study some parameters such as: The effects of ambient temperature, ambient relative humidity, forced air velocity and solar radiation intensity. The simulation results were used to validate the simplified simulation model and find solutions and proposals to achieve the human comfortable. Computational fluid dynamics (CFD) uses numerical methods to solve the problem and describe the behavior of fluids to help and visualize them via graphical simulation. CFD provides exact and detailed information specific for HVAC systems, was used to study the performance of air distribution and provides more detailed information about the flow and CFD is considered the best way to provide data and information without making theoretical or experimental methods and saving cost and time [1].

Anastasias Stamou et al. [2] used (CFD) to study the thermal comfort conditions in the stadium of the Galatsi Arena, which hosted the sports of rhythmic gymnastics and table tennis during the Olympic Games, and used CFD codes to Calculate mean velocities and temperatures were used to determine the thermal comfort indices PMV (Predicted Mean Vote) and PPD (Predicted Percentage of Dissatisfied) and to study the thermal conditions in the various regions of the Arena. The PMV and PPD are calculated from knowledge of many factors such as: activity, clothing, air temperature, air velocity, mean radiant temperature and air humidity. Computational Fluid Dynamics (CFD) can determine velocity and temperature of air then calculate the values of the PMV and PPD and the following figures illustrate the geometry of Case study and distribution of air in the Galatsi Arena (Figures 1-3).

\section{Material and Methods}

The aim of this paper is to explain the model and boundary conditions that effects in the model. In addition, clarification the main problem and the available solutions by using CFD. The study illustrates the influence of different parameters and it is used to determine the diffuser inlet, velocity, temperature, the turbulence model and the importance of radiation in air simulations. The values of these parameters would provide the best solution to achieve the human comfortable. The following figures illustrate the Case study

${ }^{*}$ Corresponding author: Khalil EE, Faculty of Engineering, Department of Mechanical Power Engineering, Cairo University, Giza, Egypt, Tel: +20 2 35676105; E-mail: khalile1@asme.org

Received July 25, 2017; Accepted July 31, 2017; Published August 04, 2017

Citation: Khalil EE, El-Bialy EM, Abdel-Maksoud W, Ashmawy ME (2017) Flow Patterns in an Air Conditioned Playground Zone of Football Stadium. J Appl Mech Eng 6: 277. doi: 10.4172/2168-9873.1000277

Copyright: @ 2017 Khalil EE, et al. This is an open-access article distributed under the terms of the Creative Commons Attribution License, which permits unrestricted use, distribution, and reproduction in any medium, provided the original author and source are credited. 
Citation: Khalil EE, El-Bialy EM, Abdel-Maksoud W, Ashmawy ME (2017) Flow Patterns in an Air Conditioned Playground Zone of Football Stadium. J Appl Mech Eng 6: 277. doi: 10.4172/2168-9873.1000277
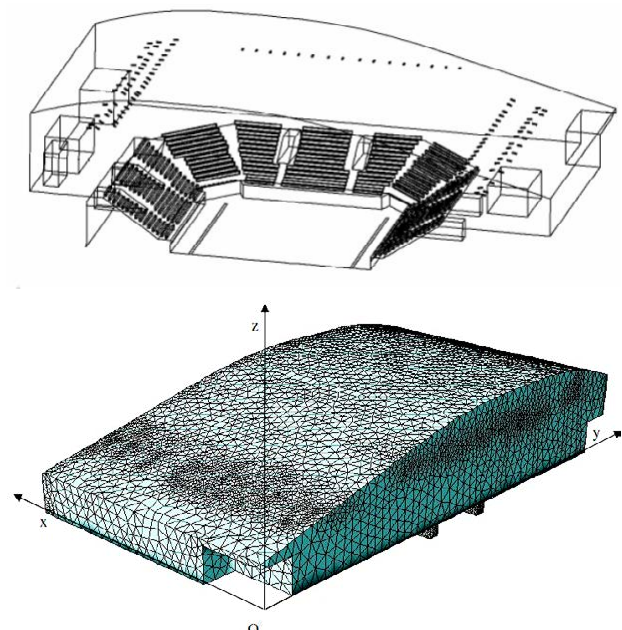

Figure 1: The geometry of the Galatsi arena [2]

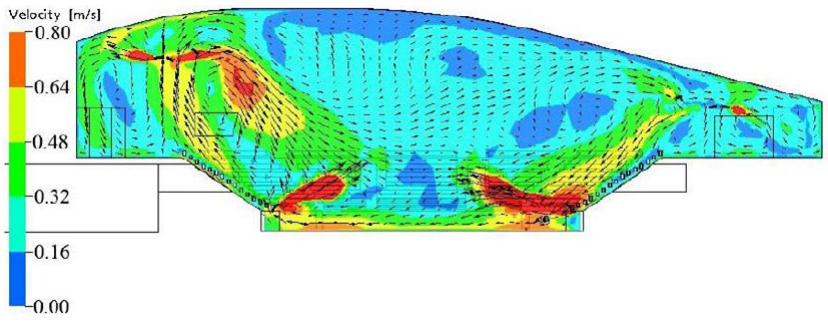

Figure 2: Velocity contours $(\mathrm{m} / \mathrm{s})$ at the plane $y-z[2]$.

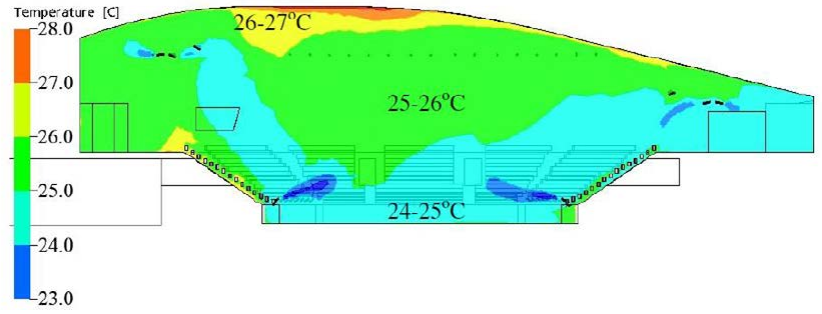

Figure 3: Temperature contours $\left({ }^{\circ} \mathrm{C}\right)$ at the plane $y-z[2]$.

(Lekhwiya Sports Stadium). CFD has been used to help determine and solve different fluid flow related problems like flow velocity, density, temperature, and chemical concentrations for playground area of stadium and get the best distribution, speed and temperature of air to achieve the human comfortable [1,2]. Qatar Stars League covered a wider scope and background materials on the subject where reference should be made for more details [3-10].

\section{Description of the Model Lekhwiya Sports Stadium and HVAC System}

The following Figure 4 illustrates the playground area of Lekhwiya Sports Stadium is based in the city of Doha and exposed to sun rays [3].

The first step to achieve the air conditioning of the stadium depends on trying to cover the largest part possible to reduce the impact of the sun's rays, and so it will be the proposed idea using a large sunshade to reduce the sun's rays and maintain the stadium's temperature, this sunshade will be of transparent material so as to allow the passage of sunlight. Figure 5 illustrates the proposed sunshade in Lekhwiya Sports Stadium.

The second step is to choose the locations of the air inlets and air outlets to achieve the human comfortable, so the playground zone is worked air conditioning systems by supplying cold air with the velocity $30 \mathrm{~m} / \mathrm{s}$ and temperature $18^{\circ} \mathrm{C}$ and then it will be inserted in the CFD program to determine the best ways to achieve the human comfortable [4-10].

The outside air temperature is about $43^{\circ} \mathrm{C}$ and enters from the large openings in the stadium with the velocity is $8.5 \mathrm{~m} / \mathrm{s}$ the pressure difference and the humidity of outside air is $70 \%$. Note that the assumptions that the outside air contains approximately $73 \% \mathrm{~N}_{2}$, $21 \% \mathrm{O}_{2}$ and $6 \% \mathrm{H}_{2} \mathrm{O}$ result of high humidity in Doha. In the other hand, Humans have evolved a breathing system that is adapted to these concentrations of gases in the atmosphere and after breathing, the concentrations of gases in air will be changed and the percentage composition of the gases after exhaling become approximately $70 \% \mathrm{~N}_{2}$, $14 \% \mathrm{O}_{2}$ and $12 \% \mathrm{H}_{2} \mathrm{O}$, and the percentage composition of the supply air is approximately $79 \% \mathrm{~N}_{2}, 21 \% \mathrm{O}_{2}$, and the percentage composition of return air is approximately $70 \% \mathrm{~N}_{2}, 14 \% \mathrm{O}_{2}$ and $10 \% \mathrm{H}_{2} \mathrm{O}$, gases must be taken into account when making calculations and simulation in the CFD program. The following figures illustrate this case of stadium air conditioning and the locations of entering outside air in the stadium.

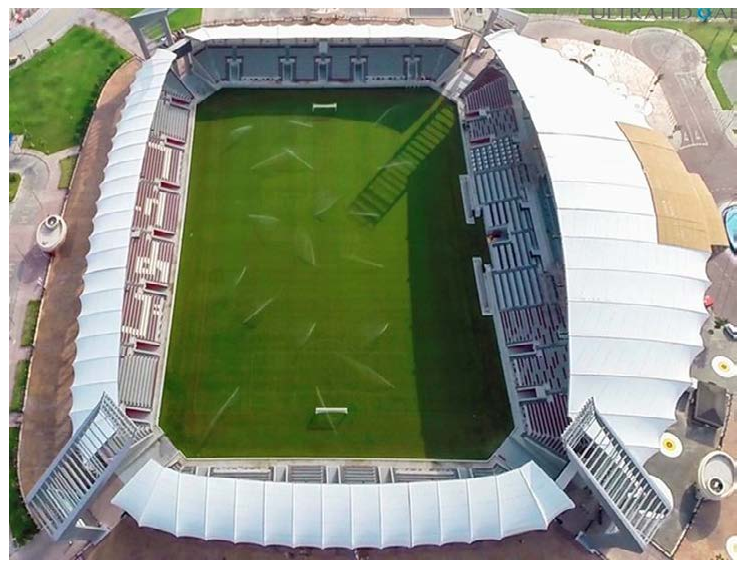

Figure 4: Lekhwiya sport stadium in Doha [4].

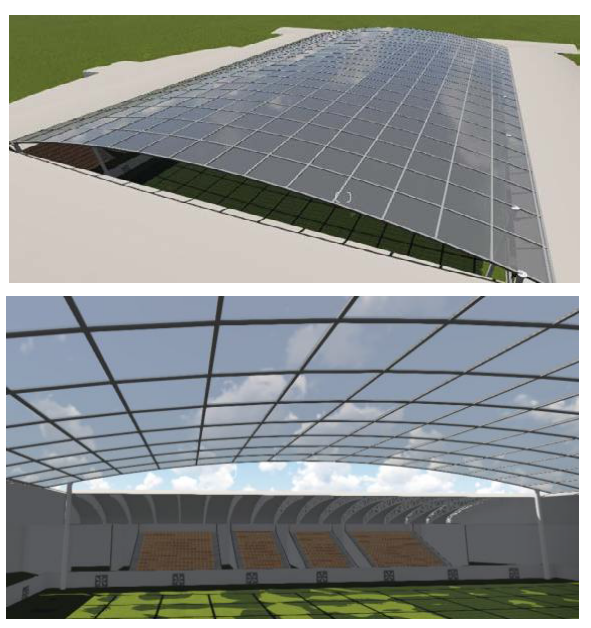

Figure 5: The proposed sunshade in stadium. 
Citation: Khalil EE, El-Bialy EM, Abdel-Maksoud W, Ashmawy ME (2017) Flow Patterns in an Air Conditioned Playground Zone of Football Stadium. J Appl Mech Eng 6: 277. doi: 10.4172/2168-9873.1000277

Page 3 of 5

\section{Mesh generation of model}

The volume is meshed into almost 27842 Nodes and 140849 Elements, using growth rate function option, meshes could be dense and small near the air supply diffusers and growing far from them, as shown in the following Figure 6.

\section{Boundary conditions}

This section will present the various boundary conditions in the following Table 1 assumed for this case.

\section{Results and Discussion}

These results will present by the following figure and note that the
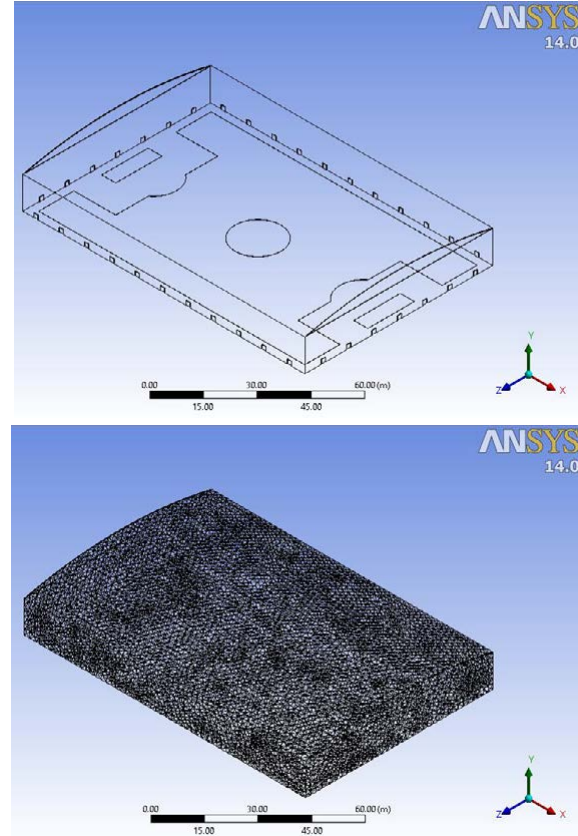

Figure 6: The mesh geometry of the playground area. distribution inside the stadium and the effects of supply cold air at the playground. The following Figure 7 shows the temperature, velocity and species of $\mathrm{H}_{2} \mathrm{O}$ contours for this Case (Figures 8-11).

The Figure 12 illustrates the results, where the distribution of temperature in the playground area is suitable and also note that the distribution of humidity where the humidity is low concentration in the playground and is gradually increasing the higher playground.

\section{Conclusion}

After presenting the results by CFD, It was conducted using Fluent CFD Code to improve the air distribution in stadium to achieve the human comfortable and work many proposed simulation to determine the best solution to achieve the target. The CFD approach provided simulation results and determined velocity, temperature, species of $\mathrm{H}_{2} \mathrm{O}$ and $\mathrm{CO}_{2}$ in the model.

1. Using the large sunshade to block out as much of the sun's rays and maintain the stadium's temperature is very important; this sunshade will be of transparent material so as to allow the passage of sunlight.

2. Using supply air jets to condition the playground area and reduce the humidly.

3. The importance of CFD in HVAC design because it allows engineers to visualize flow velocity, density, thermal impact and chemical concentrations for any region where the flow

\begin{tabular}{|l|l|}
\hline Boundary conditions & Values \\
\hline Supply air to play ground & Velocity $=30 \mathrm{~m} / \mathrm{s}$ \\
\hline & Temperature $=18^{\circ} \mathrm{C}$ \\
\hline Species $\mathrm{O}_{2}=21 \%$ \\
\hline Species $\mathrm{N}_{2}=79 \%$ \\
\hline Outside air & Velocity $=8.5 \mathrm{~m} / \mathrm{s}$ \\
\hline Temperature $=43^{\circ} \mathrm{C}$ \\
\hline Species $\mathrm{O}_{2}=21 \%$ \\
\hline Species $\mathrm{N}_{2}=73 \%$ \\
\hline Species $\mathrm{H}_{2} \mathrm{O}=6 \%$ \\
\hline
\end{tabular}

Table 1: Boundary condition for case.

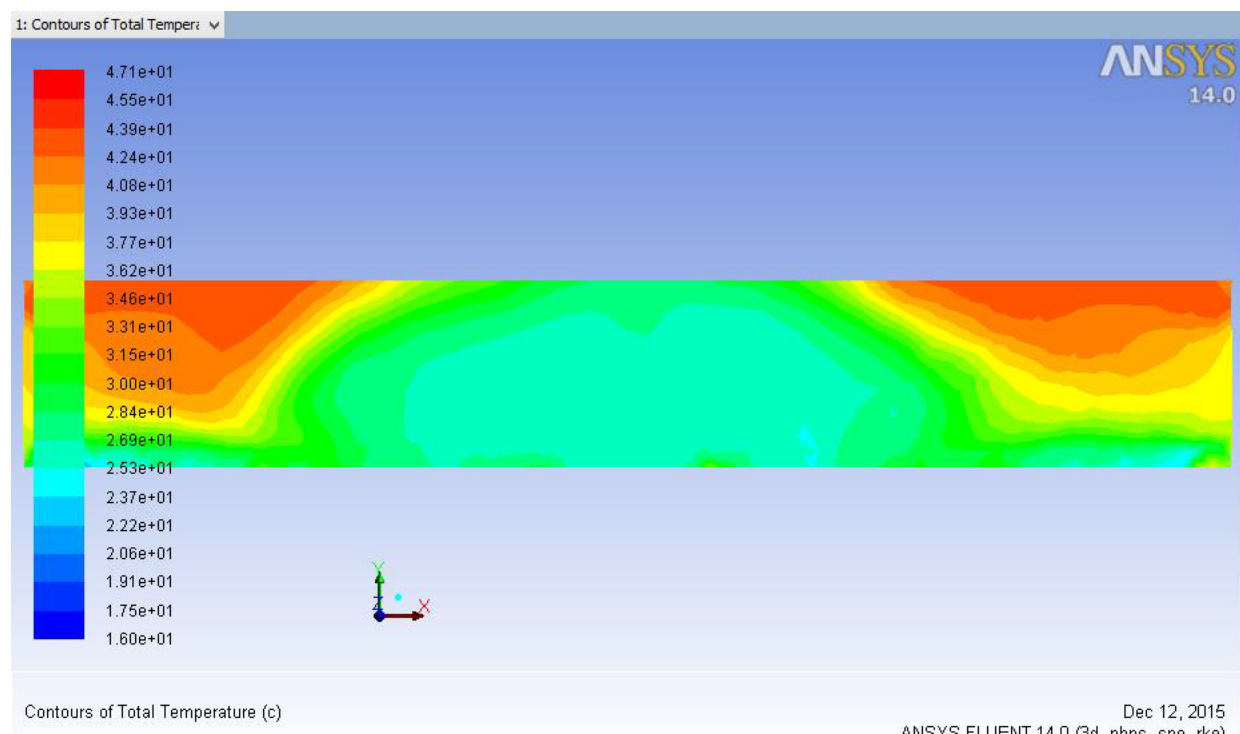

Figure 7: Temperature contours $\left({ }^{\circ} \mathrm{C}\right)$ for supply cold air to the playground - Plane $(\mathrm{Y}-\mathrm{X})$. 
Citation: Khalil EE, El-Bialy EM, Abdel-Maksoud W, Ashmawy ME (2017) Flow Patterns in an Air Conditioned Playground Zone of Football Stadium. J Appl Mech Eng 6: 277. doi: 10.4172/2168-9873.1000277

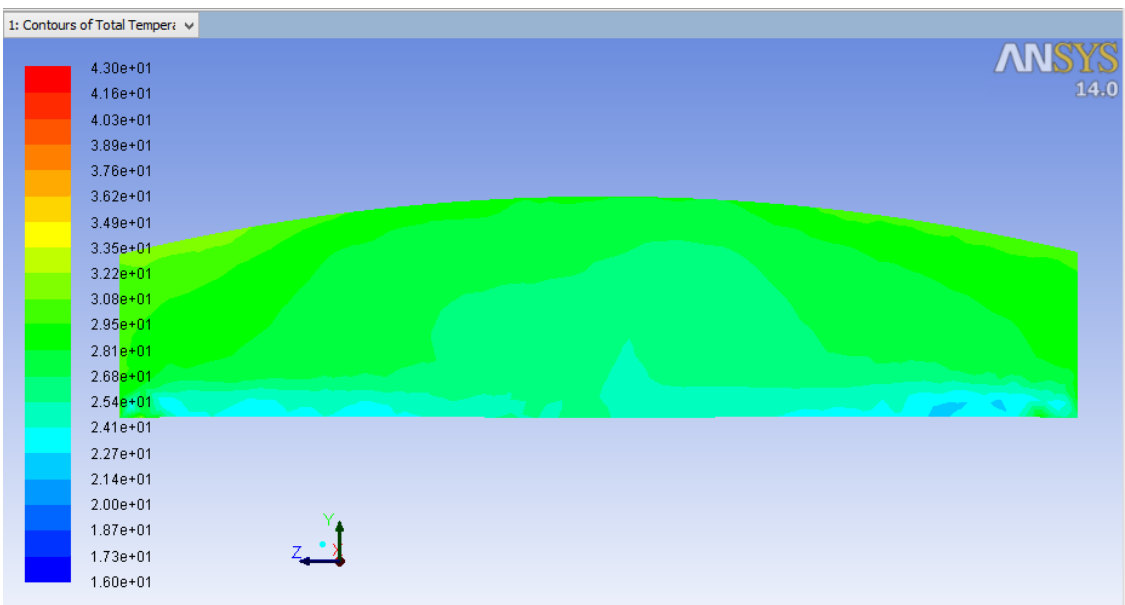

Figure 8: Temperature contours $\left({ }^{\circ} \mathrm{C}\right)$ for supply cold air to the playground - Plane $(\mathrm{Y}-\mathrm{Z})$.

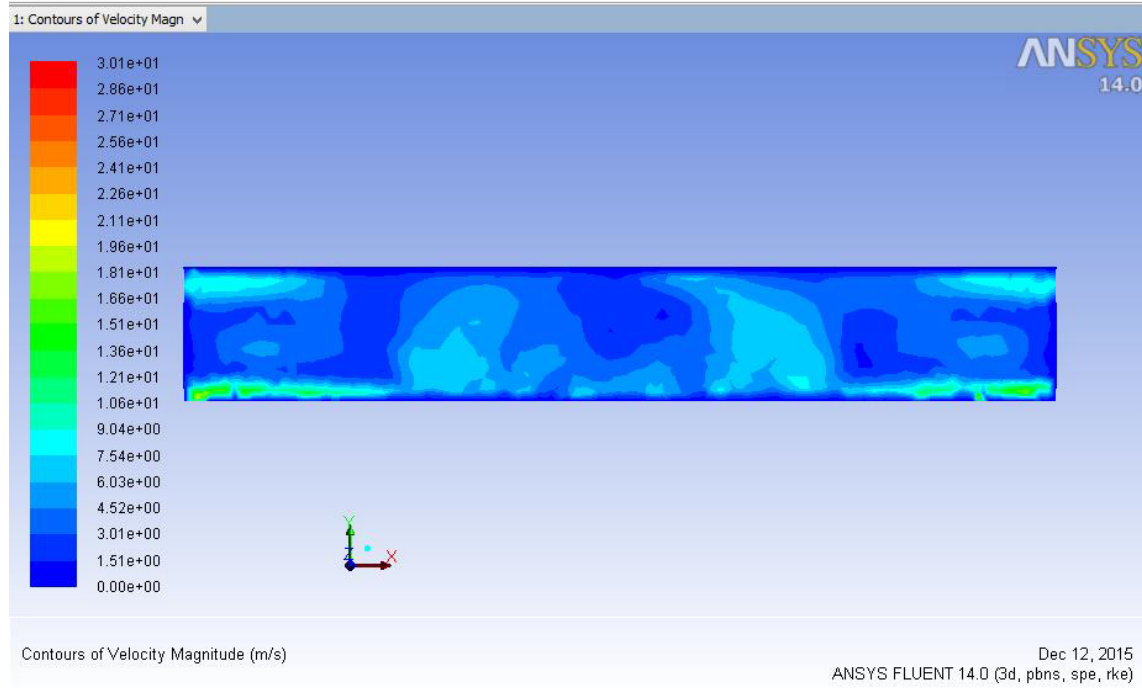

Figure 9: Velocity contours $(\mathrm{m} / \mathrm{s})$ for supply cold air to the playground - Plane $(\mathrm{Y}-\mathrm{X})$

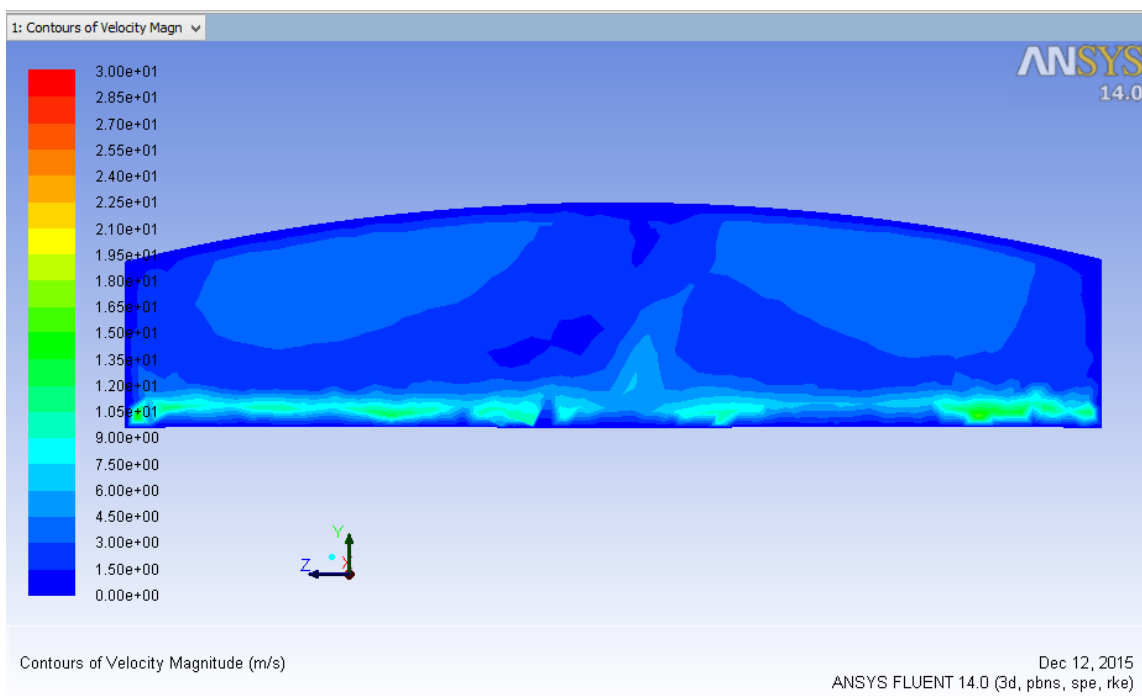

Figure 10: Velocity contours $(\mathrm{m} / \mathrm{s})$ for supply cold air to the playground - Plane (Y-Z). 
Citation: Khalil EE, El-Bialy EM, Abdel-Maksoud W, Ashmawy ME (2017) Flow Patterns in an Air Conditioned Playground Zone of Football Stadium. J Appl Mech Eng 6: 277. doi: 10.4172/2168-9873.1000277

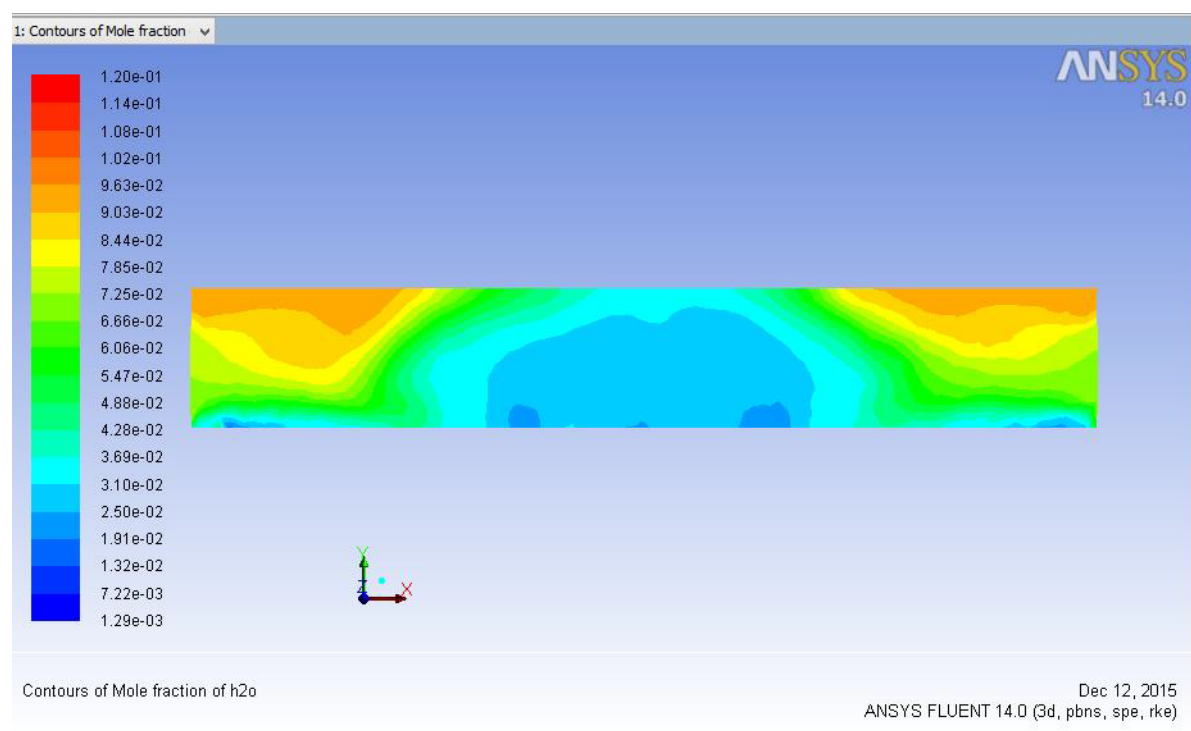

Figure 11: Species of $\mathrm{H}_{2} \mathrm{O}$ contours for supply cold air to the playground - Plane (Y-X).

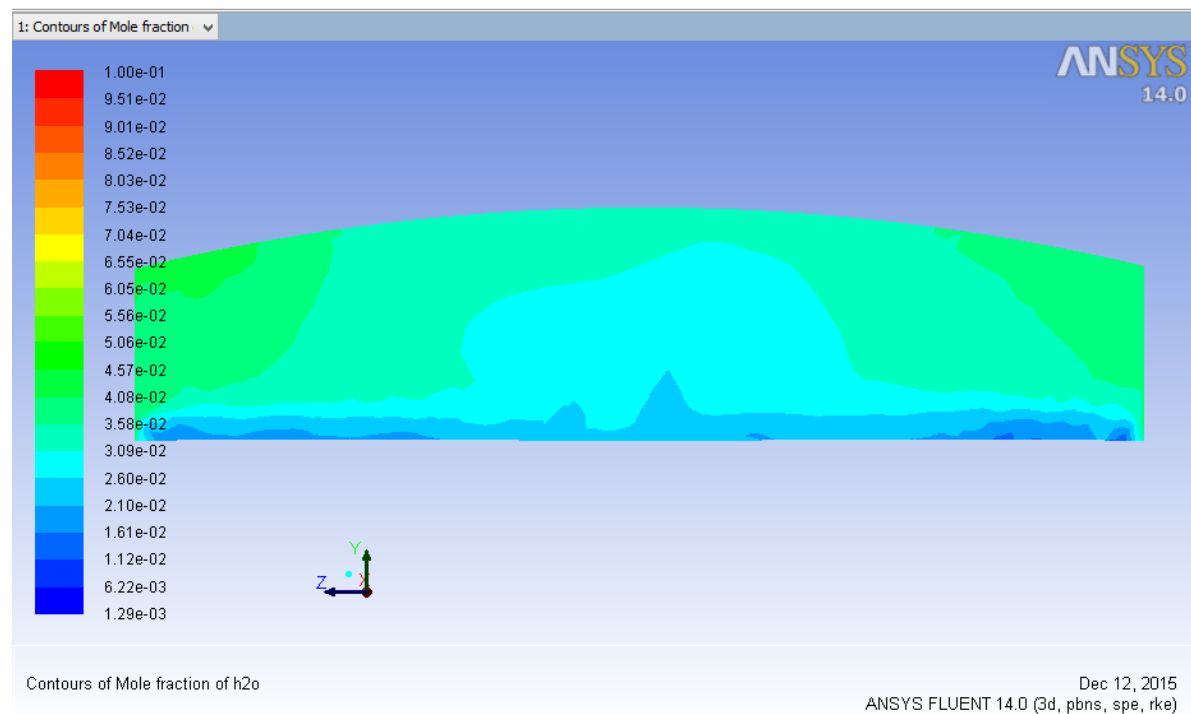

Figure 12: Species of $\mathrm{H}_{2} \mathrm{O}$ contours for supply cold air to the playground - Plane (Y-Z).

occurs. This in-turn helps engineers analyze the problem areas and suggest the best solutions. CFD is widely used across the construction industry for analysis and design optimization of an HVAC system.

\section{References}

1. Ashmawy ME (2016) Outdoor air conditioning: Qatar stadium. Faculty of Engineering, Cairo University Giza, Egypt.

2. Stamou A, Katsiris I, Schaelin A (2008) Evaluation of thermal comfort in Galats arena of the Olympics athens 2004, using a CFD model. Appl Thermal Eng 28: 1206-1215.

3. Eastman P (2015) Lekhwiya Sports Stadium. The new Doha stadium par excellence, The Lekhwiya Club, Doha, Qatar.

4. Qatar Stars League (2015) Abdullah bin Khalifa stadium.

5. Qatar Total Open (2015) WTA Premier Series: Khalifa International Tennis and Squash Complex, Doha, Qatar.
6. Jail E (2004) Using CFD for sports arena and stadia design. Ecolibrium 20-25: 160.

7. Khalil EE (2011) Flow regimes and thermal comfort in air-conditioned squash courts. 9th Annual (IECEC) San Diego, California, USA.

8. Lestinen S, Koskela H, Nyyssölä H, Sundman TL, Laine T, et al. (2012) CFDsimulation and measurement of indoor environment in a multipurpose arena The $10^{\text {th }}$ International Conference on Industrial Ventilation, France.

9. (2015) FIFA World Cup: 2022 World Cup bidding.

10. Khalil EE (2013) Air distribution in buildings. Taylor and Francis, CRC Press, USA. 